\title{
Technological Paradigm and the Social Life of the Metropolis (on the Example of Moscow)
}

\author{
Elena Barchugova ${ }^{1, *}$ Natalia Rochegova ${ }^{1, a}$
}

\begin{abstract}
${ }^{1}$ Moscow Architectural Institute (State Academy) - MarchI, Scientific Research Institute of Theory and History of Architecture and Urban Planning, the branch of the Central Institute for Research and Design of the Ministry of Construction and Housing and Communal Services of the Russian Federation, Moscow, Russia

aEmail: na.rochegova@markhi.ru

*Corresponding author. Email: ev.barchugova@markhi.ru
\end{abstract}

\begin{abstract}
The social demand for the realization of the multilayered process of the citizens' network interactions changes the face of the metropolis. Both dominant and ordinary buildings, streets, squares, parks, and water spaces are combined in a single stream of urban life. Buildings which have previously been designed to perform a single public function, operate in a new mode, which implies maximum complexity and flexibility of the functional content. User preference is given to an open-source environment. The task of translating new meanings and attitudes is assigned to the architectural designs of the urban environment, intended to ensure the social ascent of society to a new level of civic consciousness.
\end{abstract}

Keywords: network paradigm, metropolis' public spaces, open source environment, orientation and

\section{identification}

\section{INTRODUCTION}

The digital age and the related phenomenon of globalization have led to the social stratification of society all over the world, whereas it is the integrity and monolithic nature of society that has always been the key to its dynamic development and positive existence. Social disunion inevitably leads to interpersonal and global conflicts and wars and become a source of mental discomfort due to the loss of shared goals and mutual understanding. The problem is particularly acute in crowded places, in cities, and even more so in megacities. In the atmosphere of disconnection, the classical methods of consolidation, such as uniting society around a national idea, work poorly, although it is spiritual unity that is the most reliable and long-term means for keeping people together.

The search for ways to restore social balance is now in the focus of the attention of politicians, economists, cultural scientists, sociologists, and urbanists. In particular, in the reorganization of public urban spaces, where people from different social groups can be in relatively equal conditions, architects see an important role on the way to the consolidation of society. Public urban space is a neutral, averaged environment for

*This paper was funded by the Program of Fundamental Researches of the Ministry of Construction, Housing and Utilities of the Russian Federation and the Russian Academy of Architecture and Construction Sciences 2020, the Research Project 1.6.4. everyone, relative freedom from dictate, and the possibility of personal expression.

Public spaces functioning in the rhythm of the life of the city, capable of meeting the functional and spiritual needs of the citizens, when equipped with innovative technologies, can become an arena of consolidation, a pledge of the revival of the identity of a place, city, nation. It is necessary to reflect on the changes that the digital paradigm has brought to the public and private lives of citizens. The article provides an overview of the main trends in the transformation of Moscow's public spaces and the directions for their further development.

\section{THE NETWORK NATURE OF THE DIGITAL PARADIGM}

The technological paradigm caused by the development of information computer technologies is developing at a fast pace. As a result of the network relations, formerly stable forms of the public and private life of the society undergo spontaneous transformations ahead of their comprehension by specialists. Sociologists, urbanists, economists, and architects have noted an apparent lag in the analysis of the changes taking place. Regulations and laws relating to the normalization of activities using virtual networks are not being formed quickly enough. This situation is 
complicated by the fact that network relations are "extraterritorial" in their nature.

Manuel Castells, a recognized leader in the study of the processes and problems occurring in society at the beginning of the XXI century, presents the network as "a fundamental form of organization of life, and all of its types" [1]. On the basis of scientists researches, he states that: "The network is a pattern common to all life forms. Everywhere we observe life; we find networks" [ibid]. The scientist notes that these formulations are contrary to generally accepted views on the evolution of society in the usual vertical-hierarchical forms of its organization. The answer is in the explanation that "until recently, the development of the network forms of social organization was based on imperfection of the corresponding technologies". Flexibility, ability to adapt and self-regulate are recognized as the most valuable qualities of network principles of natural and social phenomena organization [2].

The intensity of the impact of new information and computer technologies on people is such that the deep layers of social organization and society's life get affected. It has to be admitted that in defining the goals and interests of transnational corporations and the global economic network, there is a lack of attention to the human being. Although the ideas of humancentrism are proclaimed, they are practically not realized or insufficiently manifested in the existing concepts of urban agglomeration development.

The changes that take place in the life of society are so significant that the theme of the end of history is sound in architectural research, assessing the state of the modern world. "In the new formulation, the issue is rather to return the substantive meaning to all forms, both old and new, restore the human fullness of content, get rid of the taste of deadness, the derivative nature of these forms. This has to be done, first of all, because the cultural-historical context of architects' professional activity is radically changing. This is primarily the collapse of a number of successive great culturalhistorical programs or utopias, within which the former architectural schools and concepts developed. It is a sense of "the end of history" [3]. "...The loss of horizon, a sense of purpose, and flattened perspective turned architecture away from real-life images in favor of autistic and self-immersion into its own structures" [4].

\section{ARCHITECTURAL PHENOMENOLOGY}

Architectural phenomenology deals with the forms and meanings of direct contacts between man and his urbanized environment. Among Russian authors, the works by K.V. Kiyanenko, A.G. Rappaport, L.V. Molodkina, I.E. Fadeeva, M.R. Nevlyutov, and other authors are devoted to these issues.
The formation of architectural phenomenology can be traced in the works of scientists who inherit and develop the views of each other: E. Husserl, M. Heidegger, H. G. Gadamer, D. Kelbaugh, C. NorbergSchulz. In his work "On the Phenomenon, Structure, And the Spirit of a Place in The Works of C. NorbergSchulz", Doctor of Architecture K.V. Kiyanenko quotes him as follows: "Science is fundamentally "abstracting" from the given in order to come to neutral, "objective" knowledge. However, it loses the everyday life-world, which should be the true concern of a man in general and urban planners and architects in particular" [5] Theoretical views of C. Norberg-Schultz, one of the leading scientists who developed the concept of "the spirit of place", are based on the position that architecture cannot rely only on scientific rationalism in the organization of the environment and human life.

"According to C. Norberg-Schulz, space cannot be perceived by an architect only as a geometric abstraction or as an object of visual perception. The notions of "space" and "character" are recognized as the capacitors of the " structure of a place". "While "space" indicates the three-dimensional organization of its constituent elements, the "character" defines the general "atmosphere", which is the most universal property of a place" [6]. At the same time, it reveals one of the main theories of the phenomenology of existence - "dwelling in the world". A human being is simultaneously placed in space (oriented in it) and correlated with a specific environmental character (identifies himself with the environment). This dual connection serves the rooting of man in the natural or man-made environment [7].

Identification and orientation are the fundamental aspects of human existence in the world. "While identification is the basis of a person's sense of belonging, orientation is a function that allows him to be the homo viator (the man traveling $-K$. Kiyanenko) that is part of his nature" [8].

Having read these lines, it is possible to notice that in today's world, both concepts - orientation and identification - have undergone changes since the moment of the writing of the text. Orientation in space has become less related to such characteristics of the urban environment as "the interrelationship of paths, edges (faces), areas, knots, and landmarks", so there may no longer be a "mental map of a place" in human consciousness - as it is being replaced by navigators. These devices, having a map of a place or a plan of the city environment downloaded in memory, simply prompt the person: turn right, walk 200 meters, etc. and you will arrive at a destination. And here the question arises about the correlation of the technical device to the person. Previously, the technological innovation allowed a person to move faster, to see further, to dig deeper, but still to be in the center of the process, to lead it. 
Today the state of things has changed: the desire to get to a particular place is carried out without strengthening one's natural abilities and can lead to a digression from the essential forms of spatial thinking that a man is used to. Life has become simpler, but the dependence on technical devices has increased. In the past, the absence or breakdown of technology forced people to strain their thinking and come up with an original way out. Today it threatens with certain powerlessness and dependence, as it is easy to get used to convenient clues, and it takes time to restore the ability to move, guided by the mental spatial schemes.

Identification with a particular place in a city (mostly public ones) was based on the nature of the localized space, its mood, which manifests the function for which it was intended. In today's city, interactions with space have become more complex. In scientific works on the relationship of function and form in architecture, for many years, there has been a tendency for their "separate" existence. From the rigid relationship between rooms or building types with their functional purpose, which existed around the mid-XX century, we moved first to multifunctionality, and then to the polyfunctionality of architectural objects. The division of functions into real and virtual spaces, exacerbating the situation, has changed the methods of placing objects of different types in the structure of the city. Any public function fixed in a particular place of the urban environment is joined by as many functions as possible (both real and virtual).

The dynamism of network relations forces an active citizen to move quickly both in real and virtual space. In this case, the primary function should be combined with the most complex set of additional services that can be implemented in one place. Correspondingly, the "character" of a place, which a person correlates with can have no strongly pronounced image, but be multifunctional. Probably, for the same reason, recently, the demand for "neutral" city spaces which users can adjust according to their needs, for example, premises in which it is possible to rent a workplace for some time (coworkings) has appeared. It is caused by the modern tendency for the increase in the number of temporary associations of specialists or organizations joining their efforts to fulfill a commission or a project, which corresponds to the dynamically changing demands of economy and business [9].

\section{INNOVATIVE PUBLIC SPACES IN MOSCOW}

"Atmosfera" coworking center is located in the shopping and entertainment center "Rio" on Leninsky Avenue in Moscow. Its workspaces are designed for a variety of formats: from a personal workplace to providing private offices for 2-4-6 people. The premises include recreation areas, playing areas with video games and mini football tables, as well as a shower and an equipped kitchen. The premises are declared as workspaces with separate areas for communication, useful acquaintances, creative interaction, exchange of experience, and ideas.

The expansion of the list of premises and services brings the office spaces of the coworkings closer to the form of rental accommodation, such as coliving, which provides a format of temporary accommodation for people with common interests or intentions. The reason for the emergence of such formations is the high cost of housing on the real estate market and the attention of the younger generation to the organization of life and business, not related to long-term stay in one place. The first network of colivings - Colivium (cohabitation of people with similar views or interests) appeared in Moscow in spring 2018.

Public spaces of the city, which include exhibition spaces, museums, and other cultural functions, often combined with the possibility to create art projects using modern media (Multimedia Art Museum in Moscow (MAMM), VR-Gallery, ARTPLAY Design and Architecture Center, etc.) have undergone even more drastic changes. In this case, the "nature" of the space is determined for a short time by media means and dynamically changes "according to the schedule". It is more difficult to identify or correlate with such variable space by order of magnitude. The principle of temporary use of neutral spaces with a number of functions becomes more widespread with the expansion of types of popular media (now multimedia projections or screens can be seen in theaters, clubs, cafes, on streets).

Thus, a modern citizen should be correlated not only with the natural and man-made environment but also with a dynamically changing virtual environment. His identity in urban space is not something immutable - it is a dynamic, complexly structured process. The researches by many authors worldwide like the works of S. Huntington, E. Toffler, G. Salikhov, A. Chumakov, O. Radugina, U. Boymatov, A. Startsev, N. Grishanin, N. Kirillina, is devoted to the problems of transformation and development of the forms of identity. All researchers note the complexity of the structure of the identity of a modern man.

In the context of globalization, the cultural space is transformed through two different vectors: integrating and differentiating. "The integrating vector manifests itself in the tendency to form a certain supranational or transnational identity, which can be designated as "civilizational identity" [10]. Integral tendencies cause the opposite reaction - differentiation and strengthening

\footnotetext{
Elena Barchugova, Natalia Rochegova, "Video Mapping from Presentation to Architecture", in Light \& Engineering / LLC Editorial of Journal "Light Technik", Moscow, Volume 24, № 4, 2016, pp. 25-30, (Web of Science)
} 
of the national cultural identity. Particular difficulties arise in the correlation of virtual and real, the combination of which provides an opportunity for an individual to actively perceive and participate in the processes taking place in several places simultaneously. "The boundaries of the space that a person could now master have instantly opened up. The virtual is perceived as real, and for the person, it becomes possible to be in many worlds simultaneously, instead of being only in the localized world of his empirical existence" [11]. The structure of human consciousness has expanded. Nowadays, it includes all world processes, which implies an increase in human social mobility. This leads to the destruction of the traditional idea of the outer world as a space of closed structures and social determinants and changes the character of interaction between a citizen and the immediate outer world of urban space.

Sociologist and researcher of urban public spaces O.V. Pachenkov, basing on the study of works of sociologists, historians, public figures (Hannah Arendt and Jurgen Habermas, Richard Sennett, Sharon Zukin, Manuel Castells, Edward Relph, Marc Auge, Zygmunt Bauman, etc.) states that the public, social sphere of activity in the modern urban space has changed its forms and locations [12]. The author notes that the unique expansion of human abilities, which took place on the basis of the development of network media means of communication, changes its perception of specific locations in the city. S. McQuire, in his book "Geomedia" asks a logical question in this regard: "Where are the borders of "here" when I am constantly in contact with "now" of other places".

The public urban location becomes active and oriented toward the interaction with the person not only within itself through the perception and manifestation of its spatial organization techniques, but also through connection with other spaces. And the more such connections are, the more active and positive it is perceived. The spatial features of a place are combined with the functions that it performs in the network of communications. Its effectiveness depends on how actively it passes through the flow of messages, money, goods, cultural, or other actions.

New forms of social life have emerged and are developing - virtual communities and their communication, interactive network forms of culture and leisure. "In other words, the way of life of a modern citizen largely takes place in "non-local places" in the traditional sense of the term" [13]

The modern metropolis is, in fact, turning into a single communication space, which is mastered by residents very actively and at different levels simultaneously. Every public facility today, whether it is a museum, exhibition, or cultural center has become a system open to interaction with the urban environment. If there is a significant event happening, it is represented in the city in many ways: in a real space with real viewers, in a virtual space through media communication with another similar object, through interactive informational small architectural objects, through street art objects. Any large cultural or public center of the city has a variety of leisure, educational, entertainment, and additional functions, the action of which occurs not only in the object itself but also in the nearest urban environment.

\section{CONCLUSION}

With the advent of the digital paradigm and the resulting globalization, large cities become included in a system of international economic interaction, where the business factor plays a major, decisive role. Technological innovations are primarily aimed at ensuring profit rather than building harmonious relations between a man and his natural or artificial environment. Ideas of humanism are not considered by a business.

The society's task is to reflect on the changes taking place and find ways to restore the lost balance in the new conditions, when the very concept of identity is lost, the stability of social and personal relations is broken, and information activity suppresses other human feelings, depriving the person of psychological comfort. Excessive presence of visual images and verbal messages clogs up "natural virtuality" - one's spiritual life and imagination. The uncontrolled flow of information disorients a person, erases clear identification with the place where he or she lives, and complicates interaction with the surrounding context. Development of norms of the safe and creative life of the network society, activation of the phenomenological component in the organization of urban space is the goal of architectural science and practice for the near future. Architects should pay special attention to the "humaneness" of the environment, which does not suppress but helps a person to realize himself in the world, his place, meaning, aspirations.

The rehabilitation of the ideas of humanism, the growth of urban dwellers' self-awareness in the complex conditions of a metropolis, and his transformation into a citizen are essential for the normalization of the relationship between the culture, business and authorities - a triad that is going through a difficult period of the collapse of hierarchical principles of organizing political, economic and secular activities. In this situation, architects and sociologists place high hopes on public spaces that have always reflected the nature and structure of power and served the transformation of man into a citizen. Role functions in public spaces are democratically aligned; the effect of the presence of each person is equally important, so the 
role of public spaces in the consolidation of society is great.

Cultural clusters, which create an additional network of public spaces promote the development of new forms of interaction between business and art activities are spontaneously arising on the territories of former industrial zones. Cultural clusters are the places of attraction for groups of people united by common interests to realize creative ideas. Today, in public spaces, events are actualized not only in reality, as such, but also in the form of broadcasts (with or without interactive participation) and in the format of presentations placed in networks capable of attracting an audience of millions of people.

The social demand for the implementation of the multilayered process of network interaction among citizens has significantly changed the image of Moscow. Historical buildings broadcasting new meanings, museums, and libraries that have expanded their functions, reconstructed industrial zones, and renovated parks - as organic parts of a living metropolis with an open-source of communication with humans - have been included in the unified stream of urban life.

\section{References}

[1] M. Castells, Informationalism, Computer Networks, and Network Society (Informatsiolizm, Kompyuternye Seti i Setevoe Obschestvo). Project International Magazine №. 41, p. 178 - 195, p. 178 [in Russian].

[2] ibid

[3] A.G. Rappaport, To the Understanding of an Architectural Form. The dissertation for The Degree of Doctor of Art History, Presented in The Form of a Scientific Report. Section: Introduction, Relevance of the Proposed Research (K Ponimaniyu Arhitekturnoy Formy. Dissertatsiya Na Soiskanie Uchenoy Stepeni Doktora Iskusstvovedeniya, Predstavlennaya V Forme Nauchnogo Doklada. Razdel: Vvedenie, Aktualnost Predlagaemogo Issledovaniya), Moscow, 2000 [Electronic resource] URL: http://www.niitiag.ru/pub/pub_cat/rappaport_a_g_k_ponimaniy u_arkhitekturnoy_formy (date of access: 18.01.2020). [in Russian].

[4] J. Pallasmaa, On the Geometry of Feelings, The Sense of Home and the Power of "Weak Architecture" (O Geometrii Chuvstv, Chuvstve Doma I Sile «Slaboy Arhitektury»), Architectural Journal, 2008 [Electronic resource] URL: http://archvestnik.ru/2008/10/24/yuhani-pallasmaa-o-geometriichuvstv-chuvstve-doma-i-sile-slaboy-arhitektury/ (date of access: 23.01.2020) [in Russian].

[5] K.V. Kiyanenko, On the Phenomenon, Structure, And the Spirit of a Place in The Works of C. Norberg-Schulz (O Fenomene, Strukture I Duhe Mesta U K. Norberg-Shultsa). Architectural bulletin, 2008, №3, pp.98-101 [in Russian]

[6] ibid

[7] ibid

[8] ibid

[9] E.V. Barchugova, N.A. Rochegova Modern Tendencies of the Social Development and Their Reflection in Architecture
(Sovremennye Tendentsii Obschestvennogo Razvitiya I Ih Otrazhenie V Arhitekture). Architecture and Modern Information Technologies, 2018, №4 (45), pp. 145-158. [Electronic resource]. http://marhi.ru/AMIT/2018/4kvart18/09_barchugova/index.php (date of access: 25.01.2020) [in Russian].

[10] O. A. Radugina, U. F. Boymatov, Problematization Of Cultural Identity in the Era of Globalization (Problematizatsiya Kulturnoy Identichnosti V Epohu Globalizatsii). The VGU Bulletin, Series: Philosophy, 2018, №.1, pp. 54-61 [in Russian].

[11] ibid

[12] O.V. Pachenkov, The Public Space of The City in The Face of Modern Challenges: Mobility and the "Misuse of Publicity" (Publichnoe Prostranstvo Goroda Pered Litsom Vyzovov Sovremennosti: Mobilnost I «Zloupotreblenie Publichnostyu») New Literary Review, 2012, №5. [Electronic resource] URL: https://www.nlobooks.ru/magazines/novoe_literaturnoe_obozre nie/117_nlo_5 2012/article/18944/ (date of access: 18.01.2020) [in Russian].

[13] ibid 